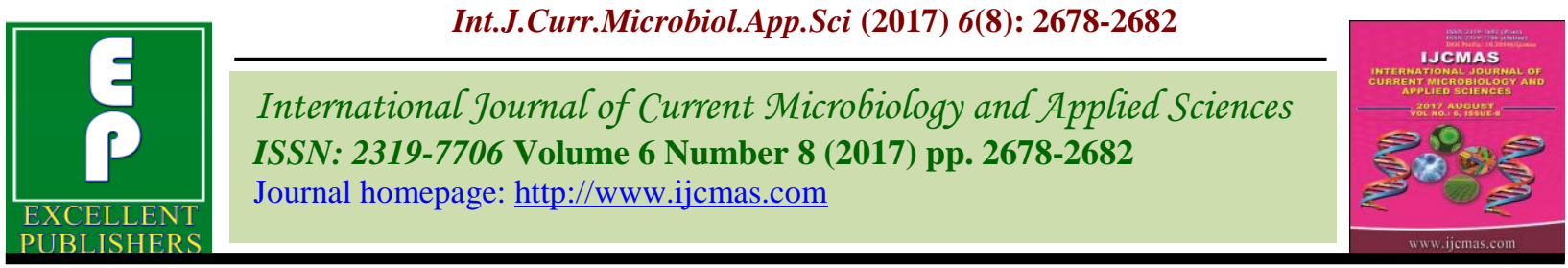

Original Research Article

https://doi.org/10.20546/ijcmas.2017.608.319

\title{
Effect of Age and Curing of Scion on Cost: Benefit Ratio of Softwood Grafting of Sapota (Achras zapota L.)
}

\author{
P. Tanuja*, D. Thippesha and N. Kavyashree \\ Department of Fruit Science, College of Horticulture, University of Agricultural and \\ Horticultural Sciences, shivamogga, Karnataka state, India \\ *Corresponding author
}

A B S T R A C T

\begin{tabular}{|l|}
\hline Ke y w or d s \\
Sapota, Curing, \\
Days after \\
grafting, Age of \\
Scion, Success \\
rate, Cost: benefit \\
ratio.
\end{tabular}

An experiment was conducted on the effect age and curing of scion on cost: benefit ratio in softwood grafting of sapota from 2014 to 2015 at the College Research Farm, Department of Fruit Science, College of Horticulture, Mudigere. The sapota grafted on 3 months age old scion resulted in maximum net income ( 18,500 per 1000 grafts) and cost: benefit ratio (1.76), which were followed by 6 months age old scion ( 16,500 per1000 grafts) and(1.57), whereas they are minimum ( 13,500 per 1000 grafts) and (1.28) in 12 months age old scion. The sapota grafted with 10 days cured scion resulted in maximum net income ( 20,750 per 1000 grafts) and cost: benefit ratio (1.93), which were followed by 8 days cured scion ( 16,750 per 1000grafts) and (1.55), whereas they are minimum ( 7,750 per 1000 grafts) and (0.75) in 0 days cured scion. The 3 months age old with 10 days cured scion resulted in maximum net income ( 22,250 per 1000 grafts) and cost: benefit ratio (2.06), which were followed by 6 months age old with 10 days cured scion ( 20,250 per 1000 grafts) and (1.88), whereas they are minimum ( 10,050 per 1000 grafts) and (1.01) in 9 months age old with 0 days cured scion. The high benefit ratio is mainly because of using the three months age old scion with ten days curing which helped in giving the higher success rate because of their actively growing.

\section{Introduction}

Sapota (Achras zapota L.) is one of the important tropical fruits belongs to family Sapotaceae. Many fruit growers were attracted towards cultivation of sapota on account of its better adoption to diverse soil and climatic conditions. Hence, there is ample scope for further increasing area under this crop. In the recent past, sapota has shown a phenomenal growth and attained the status of a major fruit crop after mango, banana and citrus. India is considered to be the largest producer of sapota in the world and it is being cultivated in an area of about 1.63 lakh hectare with a production of 14.95 lakh metric tonnes (Anon., 2013).
Though the fruit crop is having vast scope, the expansion of area under cultivation is limited due to the non-availability of sufficient genuine planting material. The major problem in sapota is difficulties in rapid clonal multiplication, since it is a difficult to root plants, comparatively takes longer time for rooting, less success and high percentage of post separation mortality of layers which necessitates resorting to grafting.

The most commercial method of propagation in sapota at present is approach grafting. But, there are difficulties in approach grafting, which is being practiced at present. This 
method is cumbersome, labour intensive and the rate of multiplication is also very low because of limited availability of scion shoots near the ground level of mother trees. So, the branches are to be bent or pandal is to be erected near to the mother tree, which makes watering difficult to the pots and involve additional expenses and labour. To overcome this problem, softwood grafting which is followed in mango and cashew may be tried. Softwood grafting was reported to be very easy, convenient in handling, involve simple skills and can be done within short time. The most important is that, it is a detached scion method. Hence, in order to have more grafting success with low cost and less labour intensive softwood grafting is being mainly practiced. Success, survivability and growth of grafts depend upon many other factors including variety, grafting method, time of grafting, age of scion and rootstock and environmental conditions (Hartmann et al., 1997).

Pre-curing of the scion and age of the scion shoots plays an important role in the success of grafting. Defoliation of the scion also plays an important role in high success rate of grafting. Successful grafting cannot be possible until the scion sticks of proper age are selected for the grafting. The age of the scion plays a key role in success of grafting.

\section{Materials and Methods}

The investigation was conducted with 18 treatments with three replications adopting factorial Randomized Block Design in the low cost polyhouse, Department of Fruit Science, College of Horticulture, Mudigere, Karnataka State during 2014 to 2015. Soft wood grafting method was followed using four to six months old rootstock. For this, the top growth of rootstock was decapitated with sharp knife and secateurs. Then longitudinal cut of $5 \mathrm{~cm}$ length was given from the terminally pruned rootstock. A scion shoot of about same thickness was selected. The length of scion was about $8-10 \mathrm{~cm}$. The basal end of scion was given two gentle sloping cuts of about $5 \mathrm{~cm}$ on opposite sides by removing the bark and a little wood giving a wedge shape. Care was taken to retain some bark on remaining two sides. The wedge shaped scion thus prepared was inserted into the ' $\mathrm{V}$ ' shaped slit of the stock and secured firmly with 150 gauge thickness transparent polythene strip of $1.5 \mathrm{~cm}$ width and 30 to $45 \mathrm{~cm}$ length, to keep the stock and scion in firm contact. The scions were covered with small transparent tubular bag to prevent entry of water into the grafted portion and also to avoid desiccation of the scion by creating humidity and microclimate near and above the graft union region.

The cost of production of grafts varied for the different experiments as follows.

\section{Results and Discussion}

\section{Effect of age of scion on cost: benefit ratio}

Grafts with 3 months age old scion (T1) resulted in maximum net income $(18,500$ per 1000grafts) followed by T2 (6 months age old scion) ( 16,500 per 1000 grafts), whereas it was minimum ( $` 13,500$ per 1000 grafts) in T4 (control-12 months age old scion). The maximum cost: benefit ratio (1.76) was observed from the treatment T1 (3 months age old scion) followed by treatment T2 (6 months age old scion) (1.57), While, the minimum cost: benefit ratio (1.28) was recorded in T4 (control). This might be due to the more success percentage and quality grafts obtained by the use of three months age old scions. Three months age old scion was most vigorous and in juvenile condition, which helped on the highest graft success Mehne (1990) observed that grafting success decreased significantly with increasing age of the scion (Tables 1 and 2). 
Table.1 Effect of age of scion on cost of production per thousand grafts in soft wood grafting of sapota

\begin{tabular}{|l|c|c|c|c|c|}
\hline \multirow{2}{*}{ Treatments } & \multicolumn{3}{|c|}{ Cost of production per 1000 grafts } & Total cost of \\
& Rootstocks & Scions & Grafting & $\begin{array}{c}\text { Maintenance } \\
\text { charges }\end{array}$ & 2000 \\
\hline $\mathrm{T}_{1}-3$ months age old scion & 7000 & 500 & 1000 & 2000 & 10,500 \\
\hline $\mathrm{T}_{2}-6$ months age old scion & 7000 & 500 & 1000 & 2000 & 10,500 \\
\hline $\mathrm{T}_{3}-9$ months age old scion & 7000 & 500 & 1000 & 2000 & 10,500 \\
\hline $\mathrm{T}_{4}-12$ months age old scion & 7000 & 500 & 1000 & & 10,500 \\
\hline
\end{tabular}

Table.2 Effect of age of scion on Cost: Benefit ratio of softwood grafting in sapota per thousand grafts

\begin{tabular}{|c|c|c|c|c|c|c|}
\hline Treatments & $\begin{array}{l}\text { Total cost of } \\
\text { production }(₹)\end{array}$ & $\begin{array}{c}\text { Percent } \\
\text { graft success }\end{array}$ & $\begin{array}{c}\text { Total number } \\
\text { of successful } \\
\text { grafts }\end{array}$ & $\begin{array}{c}\text { Gross } \\
\text { income }(₹)\end{array}$ & $\begin{array}{c}\text { Net } \\
\text { income } \\
(₹)\end{array}$ & $\begin{array}{l}\text { cost: } \\
\text { Benefit } \\
\text { ratio }\end{array}$ \\
\hline $\mathrm{T}_{1}-3$ months age old scion & 10,500 & 58.00 & 580 & 29,000 & 18,500 & $1: 1.76$ \\
\hline $\begin{array}{l}\mathrm{T}_{2}-6 \text { months age old scion Soil } \\
\text { application of } \mathrm{ZnSO} 4-50 \mathrm{~g} / \mathrm{hill}(\mathrm{SS})\end{array}$ & 10,500 & 54.60 & 540 & 27,000 & 16,500 & $1: 1.57$ \\
\hline $\begin{array}{l}\mathrm{T}_{3}-9 \text { months age old scion Soil } \\
\text { application of Boron }-20 \mathrm{~g} / \text { hill }(\mathrm{SS})\end{array}$ & 10,500 & 50.40 & 500 & 25,000 & 14,500 & $1: 1.38$ \\
\hline $\mathrm{T}_{4}-12$ months age old scion & 10,500 & 49.40 & 480 & 24,000 & 13,500 & $1: 1.28$ \\
\hline
\end{tabular}

Table.3 Effect of curing of scion on cost of production per thousand grafts in soft wood grafting of sapota

\begin{tabular}{|c|c|c|c|c|c|}
\hline \multirow[b]{2}{*}{ Treatments } & \multicolumn{4}{|c|}{ Cost of production per 1000 grafts } & \multirow[b]{2}{*}{$\begin{array}{l}\text { Total cost of } \\
\text { cultivation }\end{array}$} \\
\hline & Rootstocks & Scions & Grafting & $\begin{array}{c}\text { Maintenance } \\
\text { charges }\end{array}$ & \\
\hline $\mathrm{T}_{1^{-}} 0$ days cured scion (control) & 7000 & 500 & 1000 & 2000 & 9950 \\
\hline $\mathrm{T}_{2}-2$ days cured scion & 7000 & 500 & 1000 & 1750 & 10,250 \\
\hline $\mathrm{T}_{3}-4$ days cured scion & 7000 & 500 & 1000 & 1750 & 10,250 \\
\hline $\mathrm{T}_{4}-6$ days cured scion & 7000 & 500 & 1000 & 2000 & 10,500 \\
\hline $\mathrm{T}_{5}-8$ days cured scion & 7000 & 500 & 1000 & 2250 & 10,750 \\
\hline $\mathrm{T}_{6}-10$ days cured scion & 7000 & 500 & 1000 & 2250 & 10,750 \\
\hline
\end{tabular}


Table.4 Effect of curing of scion on cost: Benefit ratio of softwood grafting in sapota per thousand grafts

\begin{tabular}{|c|c|c|c|c|c|c|}
\hline Treatments & $\begin{array}{c}\text { Total cost of } \\
\text { production } \\
(₹)\end{array}$ & $\begin{array}{c}\text { Percent } \\
\text { graft } \\
\text { success } \\
\end{array}$ & $\begin{array}{c}\text { Total number } \\
\text { of successful } \\
\text { grafts } \\
\end{array}$ & $\begin{array}{c}\text { Gross } \\
\text { income } \\
(₹)\end{array}$ & $\begin{array}{c}\text { Net } \\
\text { income } \\
(₹) \\
\end{array}$ & $\begin{array}{c}\text { cost: } \\
\text { Benefit } \\
\text { ratio }\end{array}$ \\
\hline $\mathrm{T}_{1}-0$ days cured scion (control) & 9950 & 37.50 & 350 & 17,500 & 7750 & $1: 0.75$ \\
\hline $\mathrm{T}_{2^{-}} 2$ days cured scion Soil application of $\mathrm{ZnSO} 4-50 \mathrm{~g} / \mathrm{hill}(\mathrm{SS})$ & 10,250 & 40.00 & 400 & 20,000 & 9750 & $1: 0.95$ \\
\hline $\mathrm{T}_{3}-4$ days cured scion Soil application of Boron $-20 \mathrm{~g} / \mathrm{hill}(\mathrm{SS})$ & 10,250 & 46.38 & 450 & 22,500 & 12,250 & $1: 1.19$ \\
\hline $\mathrm{T}_{4^{-}} 6$ days cured scion & 10,500 & 50.00 & 500 & 25,000 & 14,500 & $1: 1.38$ \\
\hline $\mathrm{T}_{5^{-}} 8$ days cured scion $\mathrm{ZnSO} 40.5 \% /$ hill $(\mathrm{FA})-(\mathrm{SS})$ & 10,750 & 55.00 & 550 & 27,500 & 16,750 & $1: 1.55$ \\
\hline $\mathrm{T}_{6^{-}} 10$ days cured scion Foliar application of Boron $0.2 \% /$ hill $-(\mathrm{SS})$ & 10,750 & 62.50 & 630 & 31,500 & 20,750 & $1: 1.93$ \\
\hline
\end{tabular}

Table.5 Interaction effect of age and curing of scion on cost: benefit ratio of softwood grafting in sapota per thousand grafts

\begin{tabular}{|c|c|c|c|c|c|c|c|}
\hline $\begin{array}{l}\text { Age of the } \\
\text { scion }\end{array}$ & $\begin{array}{l}\text { Curing of } \\
\text { the scion }\end{array}$ & $\begin{array}{c}\text { Total cost of } \\
\text { production } \\
\text { (₹) }\end{array}$ & $\begin{array}{c}\text { Percent } \\
\text { Graft } \\
\text { sucess }\end{array}$ & $\begin{array}{l}\text { Successful } \\
\text { grafts }\end{array}$ & $\begin{array}{c}\text { Gross } \\
\text { income }(₹)\end{array}$ & $\begin{array}{c}\text { Net } \\
\text { income (₹) }\end{array}$ & $\begin{array}{l}\text { Cost: benefit } \\
\text { ratio }\end{array}$ \\
\hline \multirow{6}{*}{$\begin{array}{l}A_{1}-3 \text { Months } \\
\text { age old scion }\end{array}$} & $\mathrm{C}_{1^{-}}-0$ days & 9950 & 42.67 & 420 & 21,500 & 11,050 & $1: 1.11$ \\
\hline & $\mathrm{C}_{2^{-}}-2$ days & 10,250 & 48.00 & 510 & 25.500 & 15,250 & $1: 1.48$ \\
\hline & $\mathrm{C}_{3^{-}}-4$ days & 10,250 & 51.33 & 480 & 24,000 & 13,750 & $1: 1.34$ \\
\hline & $\mathrm{C}_{4}-6$ days & 10.500 & 52.67 & 520 & 26,000 & 15,500 & $1: 1.47$ \\
\hline & $\mathrm{C}_{5^{-}} 8$ days & 10,750 & 56.66 & 560 & 28,000 & 17,250 & $1: 1.60$ \\
\hline & $\mathrm{C}_{6}-10$ days & 10.750 & 64.00 & 660 & 33,000 & 22,250 & $1: 2.06$ \\
\hline \multirow{6}{*}{$\begin{array}{l}A_{2}-6 \text { Months } \\
\text { age old scion }\end{array}$} & $\mathrm{C}_{1}-0$ days & 9950 & 41.33 & 410 & 20,500 & 10,550 & $1: 1.06$ \\
\hline & $\mathrm{C}_{2}-2$ days & 10,250 & 45.67 & 450 & 22,500 & 12,250 & $1: 1.19$ \\
\hline & $\mathrm{C}_{3}-4$ days & 10,250 & 45.67 & 450 & 22,500 & 12,000 & $1: 1.17$ \\
\hline & $\mathrm{C}_{4^{-}} 6$ days & 10.500 & 51.63 & 510 & 25.500 & 15,250 & $1: 1.48$ \\
\hline & $\mathrm{C}_{5^{-}} 8$ days & 10,750 & 54.96 & 540 & 27,500 & 16,250 & $1: 1.51$ \\
\hline & $\mathrm{C}_{6^{-}} 10$ days & 10.750 & 62.92 & 620 & 31,000 & 20,250 & $1: 1.88$ \\
\hline \multirow{6}{*}{$\begin{array}{l}A_{3-9} \text { Months } \\
\text { age old scion }\end{array}$} & $\mathrm{C}_{1^{-}}-0$ days & 9950 & 40.67 & 400 & 20,000 & 10,050 & $1: 1.01$ \\
\hline & $\mathrm{C}_{2}-2$ days & 10,250 & 44.67 & 440 & 22,000 & 11,750 & $1: 1.14$ \\
\hline & $\mathrm{C}_{3}-4$ days & 10,250 & 43.59 & 470 & 23,500 & 13,250 & $1: 1.29$ \\
\hline & $\mathrm{C}_{4}-6$ days & 10.500 & 49.67 & 480 & 24,000 & 13,500 & $1: 1.30$ \\
\hline & $\mathrm{C}_{5^{-}} 8$ days & 10,750 & 54.00 & 540 & 27.000 & 16,250 & $1: 1.51$ \\
\hline & $\mathrm{C}_{6^{-}} 10$ days & 10.750 & 57.00 & 570 & 28,500 & 17,750 & $1: 1.65$ \\
\hline
\end{tabular}




\section{Effect of curing of scion on cost: benefit ratio}

The 10 days cured scion (T6) resulted in maximum net income (20,750 per 1000grafts), followed by T5 (' 16,750 per 1000 grafts), whereas it was minimum (' 7750 per1000 grafts) in T1 (control - 0 days cured scion). The maximum cost: benefit ratio (1.93) was observed from the treatment T6 (10 days cured scion) followed by treatment T5 (8days cured scion) (1.55), While, the minimum cost: benefit ratio (0.75) was recorded in $\mathrm{T} 1$ (control).

This might be due to early breaking and higher success percentage of the grafts by the use of pre- cured scions i.e., ten days pre-cured scions. The success due to procuring may be due to swelling of buds resulting in better sprouting in precured scions as explained by Maiti and Biswas (1980) (Tables 3 and 4).

\section{Interaction effect of age and curing of scion on cost: benefit ratio}

The 3 months age old scion with 10 days cured scion (A1C6) resulted in maximum net income ( 22,250 per 1000 grafts), which was followed by 6 months age old scion with 10 days cured scion (A2C6) ( 20,250 per 1000 grafts), whereas it was minimum ( 10,050 per 1000 grafts) in 9 months age old scion with 0 days cured scion $(\mathrm{A} 3 \mathrm{C} 1)$

The maximum cost: benefit ratio (2.06) was observed from the treatment 3 months age old scion with 10 days cured scion (A1C6) which was followed by the treatment with 6months age old scion with 10 days cured scion (A2C6) (1.88), While, the minimum cost: benefit ratio (1.01) was recorded in 9 months age old scion with 0 days cured scion ( $\mathrm{A} 3 \mathrm{C} 1)$. The high benefit ratio is mainly because of interaction effect i.e., by using the three months age old scion with curing which helped in giving the higher success rate because of their actively growing.

The higher percentage of survival after grafting can be attributed to the possession of better activity of the cells by the juvenile condition of the scion and higher accumulation and the translocation of the food materials by the use of cured scion. The similar observations were reported in mango by Mukherjee and Majumdar (1964) and Singh and Srivastava (1979) (Table 5).

\section{References}

Anonymous, 2013, Indian Horticultural Base. National Horticultural Board Gurgaon, India, pp. 136.

Hartmann, H. T., Kester, D. E., Davies, F. T. and Geneve, R. L., 1997, Plant propagation principles and practices. Prentice Hall of India Private Limited, New Delhi, pp. 393-480.

Mehne, B. M., 1990, Grafting trails with scions of green and chlorotic Norwaym Sprcuce (Picea abies) from forest decline regions. Grafting success with different methods and scion with different severity of damage Allgemeinem Forest and Jagdezeitigo, 161: 96-103.

Maiti, S. C. and Biswas, P., 1986, Effect of scion variety and type of scion shoot on success of epicotyl grafting of mango. Punjab Hort. J., 20(3): 152-155.

Mukherjee, S. K. and Majumdar, P. K., 1964, Effect of different factors on the success of veneer grafting in mango. Indian $J$. Hort., 21: 46-50.

Singh, N. P. and Srivastava, R. P., 1979, Studies on different aspects involved in veneer grafting in Mango. Prog. Hort, 11: 64-67.

\section{How to cite this article:}

Tanuja, P., D. Thippesha and Kavyashree, N. 2017. Effect of Age and Curing of Scion on Cost: Benefit Ratio of Softwood Grafting of Sapota (Achras zapota L.). Int.J.Curr.Microbiol.App.Sci. 6(8): 26782682. doi: https://doi.org/10.20546/ijcmas.2017.608.319 